\title{
Pengaruh Literasi Keuangan Terhadap Keputusan Investasi Mahasiswa STIE Indragiri Rengat
}

\author{
Gita Sari Gustika ${ }^{1}$, Hasanah Yaspita ${ }^{2}$ \\ ${ }^{1,2}$ Program Studi Manajemen, Sekolah Tinggi IlmuEkonomi Indragiri (STIE-I) Rengat \\ Correspondence email: ${ }^{1)}$ gita@stieindragiri.ac.id, ${ }^{2}$ hasanahyaspita@stieindragiri.ac.id
}

\begin{abstract}
Abstrak. Investasi adalah suatu bentuk penanaman dana atau modal untuk menghasilkan kekayaan, yang akan dapat memberikan keuntungan tingkat pengembalian/return baik pada masa sekarang atau dan di masa depan. Tidak sedikit masyarakat yang masih kurang memahami bagaimana cara berinvestasi yang baik dan benar sehingga banyak dari mereka yang tertipu oleh investasi dengan tawaran keuntungan bunga yang tak masuk akal dan pengelolaan investasi yang tidak jelas. Dengan menggunakan literasi keuangan maka dapat memudahkan seseorang dalam memahami dan mengetahui hal-hal tentang keuangan serta risiko keuangan yang mungkin terjadi agar terhindar dari masalah keuangan. Penelitian ini bertujuan untuk mengetahui pengaruh literasi keuangan terhadap keputusan investasi pada masyarakat khususnya mahasiswa. Studi kasus dalam penelitian ini adalah mahasiswa Strata 1 Sekolah Tinggi Ilmu Ekonomi Indragiri Rengat. Penelitian ini menggunakan pendekatan kuantitatif jenis kausal komparatif. Berdasarkan perhitungan pengambilan sampel menggunakan metode purposive sampling dengan rumus Slovin. Hasil Analisis Regresi Linear Sederhana, jika literasi keuangan sama dengan 0 (nol) maka besarnya keputusan investasi sebesar 8,141 poin, jika literasi keuangan meningkat sebesar 1 (satu) satuan maka keputusan investasi akan mengalami peningkatan sebesar 0,506 poin. Dan hasil uji parsial (Uji t, diperoleh $\mathrm{t}$ hitung sebesar 8,434 > $\mathrm{t}$ tabel 1,985, sehingga dapat disimpulkan bahwa variabel Literasi Keuangan (X) berpengaruh terhadap variabel Keputusan Investasi (Y).
\end{abstract}

Kata Kunci : Literasi Keuangan, Keputusan Investasi

\begin{abstract}
Investment is a form of investment or capital to generate wealth, which will be able to provide returns, both present and future. Not a few people still do not understand how to invest properly and correctly, so many of them are deceived by investments by offering unreasonable interest returns and unclear investment management. By using financial literacy, it can make it easier for someone to understand and know things about finance and financial risks that may occur in order to avoid financial problems. This study aims to determine the effect of financial literacy on investment decisions in society, especially students. The case study in this research is the undergraduate student of the Sekolah Tinggi IlmuEkonomi Indragiri (STIE-I) Rengat. This study uses a comparative causal quantitative approach. Based on the calculation of the sampling using purposive sampling method with the Slovin formula.Results of Simple Linear Regression Analysis, jIf financial literacy is equal to 0 (zero), the amount of investment decisions will be 8.141 points, if financial literacy increases by 1 (one) unit, investment decisions will increase by 0.506 points. And hresult of partial test ( $t$ test, obtained $t$ count is 8,434> t table 1,985, so it can be concluded that the Financial Literacy variable $(X)$ has an effect on the Investment Decision variable $(Y)$.
\end{abstract}

\section{Keywords: Financial Literacy, Investment Decisions}

\section{Pendahuluan}

Di era sekarang ini produk keuangan semakin marak berkembang dan beraneka ragam. Namun tantangannya adalah bagaimana menentukan produk dan perencanaan keuangan yang tepat. Hasil survei GoBear Financial Health Index (FHI) menunjukkan, kesadaran masyarakat Indonesia terkait perencanaan keuangan dan literasi keuangan masih rendah. Perencanaan investasi merupakan hal utama dalam mengelola keuangan karena dengan memilih investasi yang tepat akan dapat memberikan keuntungan yang berkelanjutan. Pentinya suatu perencanaan dalam pengambilan keputusan investasi, menjadikan seseorang akan lebih matang dalam menentukan keputusan investasi yang dibuat dan dapat menghindari kerugian. Pengambilan keputusan investasi hendaklah dibekali dengan pengetahuan keuangan atau literasi keuangan yang baik agar keputusan yang dibuat memiliki arah yang jelas dan tepat. Proses keputusan investasi merupakan proses keputusan yang berkesinambungan yang berjalan terus-menerus sampai tercapai keputusan investasi yang terbaik. Dalam berinvestasi terdapat lima indikator yang mempengaruhi keputusan investasi yaitu keamanan investasi, risiko investasi, tingkat pengembalian/return investasi, nilai waktu uang dan tingkat likuiditas. Dengan menggunakan faktor-faktor tersebut, investor akan menentukan keputusan investasi terbaik di antara alternatif yang tersedia. Investasi merupakan suatu sarana dimana dana dapat ditempatkan dengan harapan hal tersebut akan menghasilkan pendapatan positif dan atau menjaga atau meningkatkan nilainya. Pada masa kini masyarakat dituntut untuk berani berinvestasi agar dapat meningkatkan sumber pemasukan yang berkelanjutan. Maka dari itu setiap individu harus mampu meningkatkan pengetahuan tentang literasi keuangan sehingga pembuatan rencana keuangan akan semakin baik untuk mencapai kesejahteraan di saat usia tidak produktif lagi dan dapat menjaga stabilitas keuangan nasional. 
Hasil Survei Nasional Literasi Keuangan tahun 2013 dan 2016 menunjukkan bahwa indeks literasi keuangan masyarakat terhadap perbankan masih lebih tinggi dibandingkan dengan industri keuangan lainnya. Selain itu, indeks literasi keuangan masyarakat pada sektor Pasar Modal walaupun mengalami peningkatan dari 3,79\% menjadi 4,40\% namun masih lebih rendah dibandingkan dengan industri keuangan lainnya.

\section{Gambar 1}

Indeks literasi keuangan sektor jasa keuangan tahun 2013 dan 2016

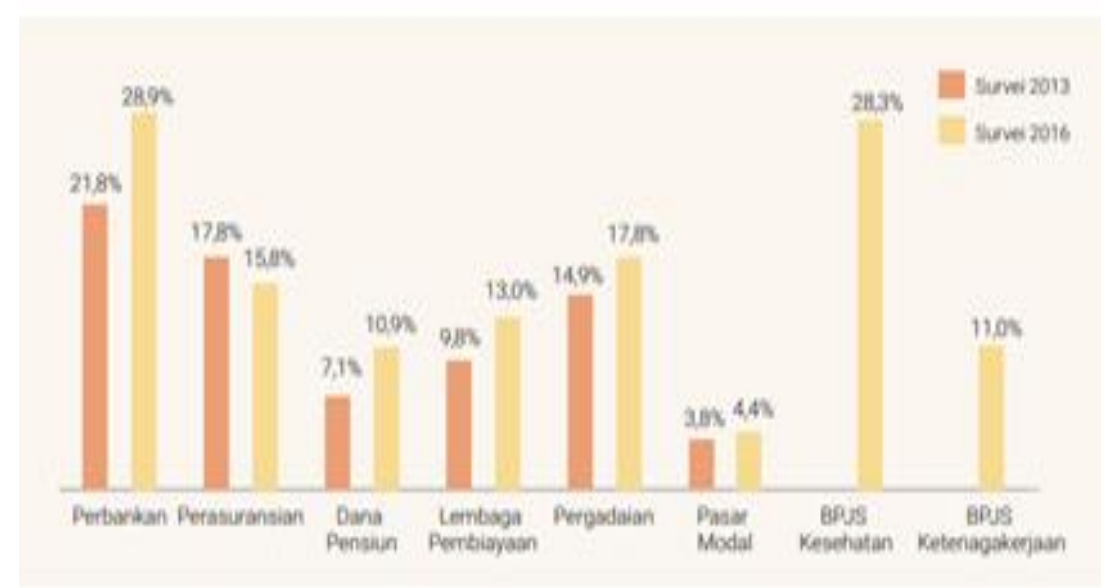

Sumber: Otoritas Jasa Keuangan 2013 dan 2016

Dalam survei 2016, terdapat pemetaan literasi keuangan terhadap Badan Penyelenggara Jaminan Sosial (BPJS) Kesehatan dan BPJS Ketenagakerjaan yang dibentuk berdasarkan Undang-Undang Nomor 24 tahun 2011 tentang Badan Penyelenggara Jaminan Sosial. Namun demikian, hasil pemetaan literasi keuangan terhadap BPJS Kesehatan dan BPJS Ketenagakerjaan tersebut tidak menjadi bagian dalam perhitungan indeks literasi keuangan dengan mempertimbangkan bahwa kepesertaan keduanya bersifat wajib. Bahkan untuk BPJS Ketenagakerjaan terdapat ketentuan sanksi yang diatur lebih lanjut dalam Peraturan Pemerintah Nomor 86 tahun 2013 tentang Tata Cara Pengenaan Sanksi Administratif kepada Pemberi Kerja Selain Penyelenggara Negara dan Setiap Orang, Selain Pemberi Kerja, Pekerja, dan Penerima Bantuan Iuran dalam Penyelenggaraan Jaminan Sosial. Kesulitan keuangan bukan hanya disebabkan oleh rendahnya tingkat penghasilan, tetapi juga disebabkan kesalahan dalam manajemen keuangan. Maka dari itu dibutuhkan literasi keuangan yang memadai. Literasi keuangan bukan ditunjukan untuk mempersulit atau mengekang orang dalam menikmati hidup serta menggunakan uang yang mereka miliki, tetapi justru dengan literasi keuangan, individu atau keluarga dapat menikmati hidup dengan menggunakan sumber daya keuangannya dengan tepat dalam rangka mencapai tujuan keuangan pribadinya.

Dengan menggunakan literasi keuangan maka dapat memudahkan seseorang dalam memahami dan mengetahui hal-hal tentang keuangan serta risiko keuangan yang mungkin terjadi agar terhindar dari masalah keuangan. Peningkatan pengetahuan keuangan yang dimiliki seseorang dapat berdampak pada partisipasi yang aktif dalam kegiatan terkait keuangan, serta sikap dan perilaku keuangan yang lebih positif pada masyarakat. Remund (2010) menyatakan bahwa literasi keuangan merupakan pengukuran terhadap pemahaman seseorang mengenai konsep keuangan, dan memiliki kemampuan dan keyakinan untuk mengatur keuangan pribadi melalui pengambilan keputusan jangka pendek yang tepat, perencanaan keuangan jangka panjang, serta memperhatikan kejadian dan kondisi ekonomi. Huston (2010) mengatakan literasi keuangan meliputi kesadaran dan pengetahuan akan instrumen keuangan dan aplikasinya di dalam bisnis dan kehidupannya. Carpena et.al (2011) menyatakan ada 3 (tiga) dimensi dari literasi keuangan yaitu (1) keterampilan menghitung, (2) pemahaman tentang keuangan dasar, dan (3) sikap terhadap keputusan keuangan. Sedangkan Willis (2008) menyatakan bahwa pengetahuan dalam konteks literasi keuangan meliputi pengetahuan, edukasi, dan informasi mengenai keuangan dan sumbernya, perbankan, deposito, kredit, asuransi, dan pajak. Pengetahuan keuangan yang dimiliki oleh seseorang tersebut kemudian berkembang menjadi keterampilan keuangan, dimana keterampilan keuangan itu sendiri didefinisikan sebagai kemampuan dalam menerapkan pengetahuan keuangan yang dimilikinya dalam kehidupan sehari-hari (Palameta et.al, 2016).

Keterampilan keuangan memungkinkan seseorang untuk dapat mengambil keputusan yang rasional dan efektif terkait dengan keuangan dan sumber ekonominya (Kurihara, 2013). Masyarakat diharapkan dapat memiliki keyakinan terhadap lembaga jasa keuangan serta produk dan layanannya setelah memiliki pengetahuan dan keterampilan yang memadai. Tidak hanya terhadap industri jasa keuangan, keyakinan terhadap kemampuan juga harus dimiliki masingmasing individu. Keyakinan tersebut termasuk keyakinan dalam melaksanakan aktivitas keuangan seperti mencatat rencana investasi dan pengeluaran, menyusun rencana anggaran, dan sebagainya (Tustin, 2010). Pengetahuan, 
keterampilan, dan keyakinan keuangan yang dimiliki oleh seorang individu berpengaruh terhadap sikap dan perilaku keuangannya. Peningkatan pengetahuan yang dimiliki seseorang dapat berdampak pada partisipasi yang aktif dalam kegiatan terkait keuangan, serta perilaku keuangan yang lebih positif pada seorang individu. Selain itu, kaitan antara perilaku dengan sikap seseorang terlihat pada seseorang yang memiliki sikap positif untuk jangka panjang kemungkinan besar akan menunjukkan perilaku keuangan yang lebih baik dibandingkan dengan seseorang yang memiliki sikap keuangan untuk jangka pendek (Atkinson \& Messy, 2012).

Berbagai studi menunjukkan bahwa literasi keuangan memiliki peran yang strategis untuk meningkatkan kemampuan pengelolaan keuangan individu. Modligiani dan Brumberg (1954) serta Friedman (1957) dalam Lusardi \& Mitchell (2014) menjelaskan bahwa konsumen diposisikan untuk mengatur simpanan dan pengeluaran secara optimal agar memberikan manfaat sepanjang masa hidupnya. Kesimpulan dari studi lain yang dilakukan oleh Lusardi \& Mitchell (2007) mengindikasikan bahwa rumah tangga yang memiliki literasi keuangan yang rendah cenderung tidak merencanakan masa pensiunnya dan memiliki aset yang rendah. Sedangkan Adams dan Rau (2011) menegaskan bahwa literasi keuangan mempunyai peran utama dalam persiapan masa pensiun. Riset menunjukkan bahwa pemahaman prinsip-prinsip dasar menabung, seperti compound interest mempunyai pengaruh langsung pada persiapan keuangan di hari tua. Boon et.al (2011) juga menemukan bahwa individu yang memiliki literasi keuangan lebih siap dalam melakukan perencanaan keuangan pribadinya. Dalam penelitian lain, Carpena, et.al (2011) menemukan bahwa edukasi keuangan mempengaruhi kesadaran dan sikap seseorang terhadap produk keuangan dan penggunaan berbagai instrumen perencanaan keuangan yang tersedia.

Chen and Volpe (1998) menjelaskan bahwa mahasiswa yang memiliki pengetahuan yang rendah akan membuat keputusan salah dalam keuangan mereka. Hal ini menunujukkan bahwa pengetahuan dibidang personal finance akan memengaruhi mahasiswa dalam mengambil keputusan keuangan yang baik. Mahasiswa merupakan salah satu komponen masyarakat dengan jumlah yang cukup besar dalam memberikan sumbangsih terhadap perekonomian. Mahasiswa sebagai generasi muda yang berintelektual akan menghadapi kompleksitas yang semakin meningkat dalam produk-produk keuangan, jasa, dan pasar. Untuk itu Mahasiswa harus bisa secara mandiri mengatur keuangannya dengan baik dan bisa bertanggungjawab atas keputusan yang telah dibuat. Mahasiswa juga dituntut untuk menerapkan ilmu yang telah didapatkan di bangku akademik dalam masalah pengelolaan keuangan.

Sekolah Tinggi Ilmu Ekonomi Indragiri Rengat menjadi salah satu wadah bagi mahasiswa untuk mempelajari dan menambah wawasan serta mengetahui literasi keuangan tentang investasi dalam mengelola keuangan. Mahasiswa sebagai kaum intelektual berperan penting bagi perubahan bangsa karena diharapkan dapat berpikir kritis dalam menyelesaikan dan memberikan solusi pada masalah yang ada di masyarakat menggunakan materi dan teori-teori yang sudah didapat melalui bangku perkuliahan. Tujuan penelitian ini adalah untuk mengetahui dan menganalisis pengaruh literasi keuangan terhadap keputusan investasi mahasiswa.

\section{Tinjauan Pustaka \\ Literasi Keuangan}

Literasi keuangan adalah sebuah pendidikan yang dibutuhkan untuk membantu orang-orang yang rentan dalam mengelola keuangan sehingga dapat mengurangi kemiskinan (Jacob, Hudson, \& Bush, 2000). Kurangnya pengetahuan tentang keuangan akan menyebabkan seseorang sulit untuk melakukan investasi. Peraturan Otoritas Jasa Keuangan Nomor 76 Tahun 2016 mendefinisikan bahwa literasi keuangan ialah pengetahuan (knowledge), keterampilan (skill) dan keyakinan (confidence) yang mempengaruhi sikap dan prilaku untuk meningkatkan kualitas pengambilan keputusan dan pengelolaan keuangan dalam rangka mencapai kesejahteraan. Menurut Huston (2010) terdapat dua dimensi dalam literasi keuangan yaitu:

1. Dimensi Pengetahuan, sebagai kumpulan pengetahuan keuangan beserta implementasinya melalui bentuk keputusan keuangan dalam kehidupan sehari-hari. Adapun lingkup dari pengetahuan keuangan hanya terbatas pada pengetahuan individu mengenai cara penggunaan produk keuangan yang diperoleh melalui pendidikan atau pengalaman pribadi.

2. Dimensi Aplikasi, adalah kemampuan individu yang dilandasi kepercayaan dirinya dalam menggunakan pengetahuan keuangannya untuk menggunakan produk keuangan dengan baik.

Menurut Strategi Nasional Literasi Keuangan Indonesia (Revisit 2017) melakukan kegiatan literasi keuangan harus berdasarkan pada: (1) pendekatan geografis, dengan memperhatikan karakteristik keunggulan daerah serta dikombinasikan dengan indeks literasi keuangan wilayah tersebut sehingga dapat diidentifikasi program kegiatan literasi keuangan serta penyediaan produk dan layanan jasa keuangan yang sesuai dengan kebutuhan masyarakat daerah tersebut. (2) pendekatan sasaran, membuat materi dan metode penyampaian yang tepat bagi kelompok masyarakat tertentu. (3) pendekatan sektoral, dengan melakukan pemetaan pada aspek pembentuk literasi keuangan di industri jasa keuangan seperti Perbankan, Pasar Modal, Perasuransian, Lembaga Pembiayaan, Dana Pensiun, dan Pergadaian sehingga dapat diketahui industri mana yang masih memerlukan upaya peningkatan lebih optimal untuk meningkatkan literasi keuangan. 
Strategi Nasional Literasi Keuangan Indonesia (SNLKI) (revisit 2017) juga menyebutkan bahwa terdapat empat prinsip dasar yang perlu dilakukan dalam melaksanakan literasi keuangan, yakni: terencana dan terukur, berorientasi pada pencapaian, berkelanjutan, dan kolaborasi. Sesuai survei yang dilakukan Otoritas Jasa Keuangan, tingkat literasi penduduk dibagi menjadi empat bagian :

1. Well Literate, yaitu penduduk memiliki pengetahuan dan keyakinan terhadap lembaga jasa keuangan serta poduknya termasuk fitur, manfaat dan risiko, hak dan kewajiban terkait jasa keuangan dan produknya, serta memiliki ketrampilan dalam menggunakan jasa keuangan dan produknya.

2. Sufficient Literate, yaitu penduduk memiliki pengetahuan dan keyakinan tentang adanya jasa keuangan serta poduknya termasuk fitur, manfaat dan risiko, hak dan kewajiban terkait jasa keuangan dan produknya

3. Less Literate, yaitu penduduk hanya memiliki pengetahuan tentang adanya lembaga jasa keuangan, produk dan jasa keuangan.

4. Not Literate, yaitu penduduk tidak memiliki pengetahuan dan keyakinan terhadap lembaga jasa keuangan serta produknya serta penduduk tidak memiliki keterampilan dalam menggunakan jasa keuangan dan produknya.

Terdapat beberapa indikator yang dapat digunakan untuk mengetahui tingkat literasi keuangan seseorang yang digunakan pada penelitian sebelumnya, yaitu Mandle and Klein (2007) meneliti tingkat literasi keuangan seseorang dengan menggunakan 4 indikator, yakni : (1) Income, (2) Money management, (3) Spending \& credit, (4) saving \& investing. Anggraeni (2015) literasi keuangan mempengaruhi cara berpikir seseorang terhadap kondisi keuangan serta mempengaruhi pengambilan keputusan yang strategis dalam hal keuangan dan pengelolaan yang lebih baik bagi pemilik usaha. Sedangkan Chiara Monticone (2010) menjelaskan bahwa faktor yang dapat mempengaruhi literasi keuangan adalah karakteristik demografi berupa gender, etnis, pendidikan dan kemampuan kognitif serta latar belakang keluarga, kekayaan dan preferensi waktu. We cannot avoid that the times have brought us to an era of all digital technology which requires skills and knowledge in its operation and an era of human resources who are ready to compete both nationally and internationally (Fransinatra et al., 2020). Secara umum indikator-indikator literasi keuangan berdasarkan beberapa pendapat peneliti sebelumnya maka indikator literasi keuangan yang digunakan dalam penelitian investasi.

\section{Keputusan Investasi}

Menurut Jogiyanto (2016) investasi didefinisikan sebagai penundaan konsumsi sekarang untuk digunakan dalam produksi yang efesien selama periode waktu tertentu. Sedangkan Menurut Sadono Sukirno (2016) investasi adalah aktivitas pengeluaran atau pembelanjaan penanam modal untuk membeli barang-barang modal dan juga perlengkapan-perlengkapan produksi dengan tujuan menambah kemampuan memproduksi barang dan jasa yang tersedia dalam perekonomian. Selain itu kegiatan investasi yang dilakukan oleh masyarakat secara terus menerus akan meningkatkan kegiatan ekonomi dan kesempatan kerja, meningkatkan pendapatan nasional dan meningkatkan taraf kemakmuran masyarakat. Peranan ini bersumber dari tiga fungsi penting dari kegiatan investasi, yakni (1) investasi merupakan salah satu komponen dari pengeluaran agregat, sehingga kenaikan investasi akan meningkatkan permintaan agregat, pendapatan nasional serta kesempatan kerja; (2) pertambahan barang modal sebagai akibat investasi akan menambah kapasitas produksi; (3) investasi selalu diikuti oleh perkembangan teknologi. Keputusan investasi merupakan proses keputusan yang berkesinambungan yang berjalan terus-menerus sampai tercapai keputusan investasi yang terbaik. Menurut Tandelilin (2010) alasan seseorang melakukan investasi antara lain: (1) untuk mendapatkan kehidupan yang lebih layak di masa mendatang, (2) mengurangi tekanan inflasi.; dan (3) dorongan untuk menghemat pajak

Menurut Putri \& Rahyuda (2017) dalam berinvestasi terdapat lima indikator yang mempengaruhi keputusan investasi yaitu keamanan investasi, risiko investasi, tingkat pengembalian/return investasi, nilai waktu uang dan tingkat likuiditas. Dengan menggunakan faktor-faktor tersebut, investor akan menentukan keputusan investasi terbaik di antara alternatif yang tersedia.

\section{Hipotesis}

Berdarkan pada kerangka konseptual yang telah digambarkan dan di jelaskan diatas maka hipotesis penelitian ini dirumuskan sebagai berikut : Literasi Keuangan dapat berpengaruh terhadap Keputusan Insvestasi.

\section{Metode}

Populasi dalam penelitian ini adalah seluruh mahasiswa Strata 1 STIE-I Rengat. Jumlah populasi adalah 3.744 mahasiswa aktif periode 2020-2021. Teknik pengambilan sampel dilakukan dengan menggunakan purposive sampling dimana sampel diambil dengan pertimbangan tertentu. Teknik ini dilakukan untuk mendapatkan sampel yang sesuai dengan kebutuhan penelitian. Sampel pencarian data uji coba melalui angket/kuisioner dalam penelitian ini adalah 97 orang. Sampel yang ditetapkan harus mahasiswa semester 7 yang sudah menerima mata kuliah yang berkaitan dengan investasi dan yang sudah bekerja. Adapun jenis dan sumber data yang dikumpulkan dalam penelitian ini adalah data 
sekunder yaitu data primer. Data primer ini didapat dari hasil pembagian angket atau kuesioner pada sampel yang telah ditetapkan sebelumnya.

\section{Uji Instrumen \\ Uji Validitas}

Menurut Ghozali (2012) uji validitas digunakan untuk mengukur sah atau tidaknya suatu kuesioner atau angket. Suatu kuesioner dikatakan valid jika pertanyaan atau pernyataan pada kuesioner mampu untuk mengungkapkan sesuatu yang akan diukur oleh kuesioner tersebut. Pengujian validitas ini menggunakan Corrected Total Correlation yaitu dengan cara menghitung korelasi antara bobot yang diperoleh dari pernyataan atau pertanyaan kuesioner. Suatu pernyataan atau pertanyaan dikatakan valid jika nilai $r$ hitung $>r$ tabel.

\section{Uji Reliabilitas}

Reliabilitas adalah alat untuk mengukur suatu kuesioner yang merupakan indikator dari variabel. Jika jawaban responden terhadap pernyataan stabil atau konsisten dari waktu ke waktu maka kuesioner tersebut bisa dikatakan reliabel atau handal. Butir kuesioner dikatakan reliabel jika Cronbach's Alpha > 0,06 (Gozhali, 2012).

\section{Uji Asumsi Klasik \\ Uji Normalitas}

Uji Normalitas bertujuan untuk mengetahui apakah dalam model regresi, variabel pengganggu atau residual memiliki distribusi normal atau tidak. Pengujian normalitas dilakukan dengan uji Kolmogorov-Smirnov yang dilakukan terhadap nilai residual. Pengujian ini dilakukan dengan melihat nilai sig.(2-tailed). Jika data memiliki tingkat signifikansi lebih besar dari 0,05 atau 5\% maka dapat disimpulkan bahwa data terdistribusi normal. Sebaliknya, jika data memiliki tingkat signifikansi lebih kecil dari 0,05 atau 5\% maka dapat disimpulkan bahwa data terdistribusi tidak normal. Penelitian ini merupakan penelitian jenis kausal dengan pendekatan kuantitatif. Penelitian kasual komparatif merupakan penelitian yang mencari informasi terjadinya hubungan sebab akibat dan peneliti berusaha melacak kembali hubungan sebab akibat tersebut. Penelitian kausal juga digunakan untuk mengukur seberapa kuat hubungan dan pengaruh antar variabelnya.

\section{Uji Multikolinearitas}

Uji Multikolinearitas bertujuan untuk mengetahui apakah pada model regresi terdapat adanya korelasi antar variabel independen. Jika tidak terjadi korelasi antar variabel independen maka termasuk model regresi yang baik. Menurut Ghozali (2009) multikolinearitas dapat dilihat dari nilai tolerance dan VIF 41 (Variance Inflation Factor). Jika nilai tolerance yang rendah sama dengan nilai VIF tinggi, maka menunjukkan adanya kolinearitas yang tinggi (karena $\mathrm{VIF}=1 /$ Tolerance). Nilai cutoff yang menunjukkan tidak terjadi multikolinearitas adalah nilai tolerance $>0,10$ atau sama dengan nilai VIF $<10$.

\section{Uji Heteroskedastisitas}

Uji Heteroskedastisitas bertujuan untuk menguji apakah dalam model regresi terjadi ketidaksamaan variance dari residual satu pengamatan ke pengamatan yang lain. Model regresi yang baik adalah ketika tidak terjadi heteroskedastisitas atau jika variance dari residual satu pengamatan ke pengamatan lain tetap (Ghozali, 2009). Pengujian dilakukan dengan uji Glejser yaitu dengan meregres variabel independen terhadap nilai absolute residual. Jika variabel independen signifikan secara statistik 42 memengaruhi variabel dependen, maka ada indikasi terjadi heteroskedastisitas. Kriteria yang digunakan untuk menyatakan apakah terjadi heteroskedastisitas atau tidak diantara data penelitian dapat dijelaskan dengan menggunakan koefisien signifikansi. Dasar pengambilan keputusannya adalah jika signifikansi kurang dari 0,05 maka terjadi heteroskedastisitas, sedangkan jika signifikansi lebih dari 0,05 maka tidak terjadi heteroskedastisitas. Kedua dengan menggunakan diagram scatterplot. Dasar analisis terjadi heteroskedastisitas adalah :

1. Jika ada pola tertentu, seperti titik-titik yang ada membentuk pola tertentu yang teratur (bergelombang, melebar kemudian menyempit), maka mengindikasikan telah terjadi heteroskedastisitas.

2. Jika tidak ada pola yang jelas, serta titik-titik menyebar diatas dan dibawah angka 0 pada sumbu $\mathrm{Y}$, maka tidak terjadi heteroskedastisitas.

\section{Uji Regresi Linier Sederhana}

Uji regresi linier sederhana digunakan untuk mengukur pengaruh satu variabel bebas terhadap varibel terikat (Sunyoto, 2012). Bentuk umum dari persamaan regresi linier sederhana sebagai berikut: $Y=\alpha+\beta x+e$ 
Gita Sari Gustika dan Hasanah Yaspita, Pengaruh Literasi Keuangan Terhadap Keputusan Investasi Mahasiswa STIE Indragiri Rengat

Dimana : $\mathrm{Y}=$ Variabel dependen (Keputusan Investasi); $\alpha=$ Konstanta; $\beta=$ Koefisien regresi; $\mathrm{X}=$ Variabel independen (Literasi Keuangan)

\section{Uji Simultan (F)}

Uji Simultan digunakan untuk mengetahui pengaruh variabel bebas (independent) terhadap variabel terikat (dependen). Kaidah pengambilan keputusannya adalah :

1) Jika $F_{\text {hitung }}>F_{\text {tabel}}$, maka Ha diterima dan Ho ditolak, artinya secara simultan Literasi Keuangan berpengaruh terhadap keputusan investasi mahasiswa.

2) Jika $F_{\text {hitung }}<F_{\text {tabel, }}$ maka Ha ditolak dan Ho diterima, artinya secara simultan Literasi Keuangan berpengaruh terhadap keputusan investasi mahasiswa.

Taraf nyata atau derajat keyakinan yang digunakan adalah sebagai berikut : $\alpha=5 \%, \mathrm{df}=\mathrm{n}-\mathrm{k}-1$. Dengan bentuk hipotesis sebagai berikut :

Ho $: b_{1}=0$ Tidak ada pengaruh yang berarti antara Literasi Keuangan berpengaruh terhadap keputusan investasi mahasiswa STIE Indragiri Rengat

$\mathrm{Ha}: \mathrm{b}_{1} \neq 0$ Ada pengaruh yang berarti antara Literasi Keuangan berpengaruh terhadap keputusan investasi mahasiswa STIE Indragiri Rengat

\section{Uji Parsial (t)}

Uji t digunakan untuk menguji koefisien regresi secara parsial atau terpisah dari variabel bebas lainnya. Untuk mengetahui apakah masing-masing variabel bebas berpengaruh terhadap variabel terikat. Kaidah pengambilan keputusannya adalah :

1) Jika $t_{\text {hitung }}>t_{\text {tabel }}$ maka Ha diterima dan Ho ditolak, yang berarti Literasi Keuangan mempengaruhi keputusan investasi mahasiswa STIE Indragiri Rengat

2) Jika $t_{\text {hitung }}>t_{\text {tabel }}$ maka Ha ditolak dan Ho diterima, yang berarti Literasi Keuangan tidak mempengaruhi keputusan investasi mahasiswa STIE Indragiri Rengat

Dengan bentuk hipotesis sebagai berikut :

Ho $: b_{1}=0$ Tidak ada pengaruh Literasi Keuangan terhadap keputusan investasi mahasiswa STIE Indragiri Rengat Ha $: b_{1} \neq 0$ Ada pengaruh Literasi Keuangan terhadap keputusan investasi mahasiswa STIE Indragiri Rengat.

\section{Koefisien Determinasi}

Koefisien Determinasi $\left(\mathrm{R}^{2}\right)$ adalah satu ukuran yang digunakan untuk mengukur pengaruh variabel independen terhadap variabel dependen, dengan $0<\mathrm{R}^{2}<1$

\section{Hasil \\ Uji Validitas}

Tabel 1

Uji Validitas Literasi Keuangan (X)

\begin{tabular}{|l|l|l|l|}
\hline Kode soal & $\mathbf{R}_{\text {tabel }}$ & $\mathbf{R}_{\text {hitung }}$ & Keterangan \\
\hline P1 & 0,1996 & 0,362 & Valid \\
\hline P2 & 0,1996 & 0,514 & Valid \\
\hline P3 & 0,1996 & 0,431 & Valid \\
\hline P4 & 0,1996 & 0,711 & Valid \\
\hline P5 & 0,1996 & 0,771 & Valid \\
\hline P6 & 0,1996 & 0,734 & Valid \\
\hline P7 & 0,1996 & 0,661 & Valid \\
\hline P8 & 0,1996 & 0,824 & Valid \\
\hline
\end{tabular}

Sumber : Olahan data

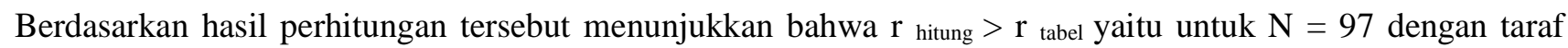
signifikan 5\% adalah 0,1996. Demikian dapat dikatakan Literasi Keuangan (X) yang digunakan dalam penelitian ini sudah valid semua. 
Gita Sari Gustika dan Hasanah Yaspita, Pengaruh Literasi Keuangan Terhadap Keputusan Investasi Mahasiswa STIE Indragiri Rengat

Tabel 2

Uji Validitas Keputusan Investasi (Y)

\begin{tabular}{|l|l|l|l|}
\hline Kode soal & $\mathbf{R}_{\text {tabel }}$ & $\mathbf{R}_{\text {hitung }}$ & Keterangan \\
\hline P1 & 0,1996 & 0,506 & Valid \\
\hline P2 & 0,1996 & 0,175 & Tidak Valid \\
\hline P3 & 0,1996 & 0,207 & Valid \\
\hline P4 & 0,1996 & 0,681 & Valid \\
\hline P5 & 0,1996 & 0,754 & Valid \\
\hline P6 & 0,1996 & 0,686 & Valid \\
\hline P7 & 0,1996 & 0,738 & Valid \\
\hline P8 & 0,1996 & 0,709 & Valid \\
\hline
\end{tabular}

Sumber : Olahan data

Berdasarkan hasil perhitungan tersebut menunjukkan bahwa 8 pernyataan $\mathrm{r}_{\text {hitung }}>\mathrm{r}_{\text {tabel }}$ yaitu untuk $\mathrm{N}=97$ dengan taraf signifikan 5\% adalah 0,1996 dan 1 pernyataan menunjukkan $\mathrm{r}_{\text {hitung }}<\mathrm{r}_{\text {tabel. }}$ Demikian dapat dikatakan bahwa Keputusan Investasi (Y) yang digunakan dalam penelitian ini 8 pernyataan valid dan 1 pernyataan tidak valid. Item pernyataan pada instrumen angket yang dinyatakan tidak valid harus di buang dan tidak dimasukan pada instrumen untuk menguji hipotesis.

\section{Uji Reliabilitas}

Uji coba yang telah dilakukan dapat diketahui bahwa hasil Cronbach's Alpha setiap variabel lebih besar dari standar minimal Cronbach's Alpha yang disyaratkan yaitu 0,60, maka variabel Literasi Keuangan (X) dengan nilai 0,781 reliabel dan layak di gunakan dalam pengambilan data.

Tabel 3

Uji Reliabilitas Literasi Keuangan (X)

\begin{tabular}{|l|l|}
\hline Cronbach's Alpha & N of Items \\
\hline .781 & 8 \\
\hline
\end{tabular}

Sumber : Olahan data

Tabel 4

Uji Reliabilitas Keputusan Investasi

\begin{tabular}{|l|l|}
\hline Cronbach's Alpha & N of Items \\
\hline .739 & 7 \\
\hline
\end{tabular}

Sumber : Olahan data

Uji coba yang telah dilakukan dapat diketahui bahwa hasil Cronbach's Alpha setiap variabel lebih besar dari standar minimal Cronbach's Alpha yang disyaratkan yaitu 0,60, maka variabel Keputusan Investasi (Y) dengan nilai 0,739 reliabel dan layak di gunakan dalam pengambilan data.

\section{Uji Asumsi Klasik \\ Uji Normalitas}

Tabel 5

Hasil Uji Normalitas

\begin{tabular}{|ll|l|}
\hline & & Unstandardized Residual \\
\hline $\mathrm{N}$ & Mean & 97 \\
Normal Parameters ${ }^{\mathrm{a}, \mathrm{b}}$ & Std. Deviation & .0000000 \\
& Absolute & 3.56259177 \\
& Positive & .136 \\
Most Extreme Differences & Negative & .064 \\
& & -.136 \\
Kolmogorov-Smirnov Z & & 1.338 \\
Asymp. Sig. (2-tailed) & .056 \\
\hline
\end{tabular}

Sumber : Olahan data

Data tertera pada tabel di atas dapat diketahui bahwa nilai Kolmogorov-smirnov Z yaitu 1,338. Karena nilai ini lebih besar dari 0,05, maka dapat disimpulkan bahwa populasi data variabel X (Literasi Keuangan) dan Y (Keputusan Investasi) berdistribusi normal. 
Gita Sari Gustika dan Hasanah Yaspita, Pengaruh Literasi Keuangan Terhadap Keputusan Investasi Mahasiswa STIE Indragiri Rengat

\section{Uji Multikolinieritas}

Tabel 6

Uji Multikolinieritas

\begin{tabular}{|c|c|c|c|c|c|c|c|c|}
\hline \multirow{2}{*}{\multicolumn{2}{|c|}{ Model }} & \multicolumn{2}{|c|}{ Unstandardized Coefficients } & \multirow{2}{*}{$\frac{\text { Standardized Coefficients }}{\text { B eta }}$} & \multirow{2}{*}{$\mathrm{t}$} & \multirow{2}{*}{ Sig. } & \multicolumn{2}{|c|}{ Collinearity Statistics } \\
\hline & & B & Std. Error & & & & Tolerance & VIF \\
\hline 1 & (Constant) & $\begin{array}{r}8.141 \\
506\end{array}$ & 1.189 & & 6.846 & .000 & & \\
\hline & $\mathrm{X}$ & .506 & .060 & 654 & 8.434 & .000 & 1.000 & 1.000 \\
\hline
\end{tabular}

Sumber : Olahan data

Data yang tertera pada tabel 6 di atas dapat diketahui bahwa nilai tolerance variabel X (Literasi Keuangan) yaitu 1,000 dengan VIF 1,000. Nilai ini lebih kecil dari 10,00 dan 0,100, dan dapat disimpulkan tidak terdapat multikolinieritas pada variabel dengan kata lain model regresi ini terbebas dari gejala multikolinieritas.

\section{Uji Heteroskedastisitas}

Tabel 7

Uji Heteroskedastisitas

\begin{tabular}{|l|l|l|l|l|l|l|}
\hline \multirow{2}{*}{ Model } & \multicolumn{2}{|l|}{ Unstandardized Coefficients } & Standardized Coefficients & \multirow{2}{*}{$\mathrm{t}$} \\
\cline { 3 - 7 } & $\mathrm{B}$ & Std. Error & Beta & 2.718 \\
\hline \multirow{2}{*}{1} & (Constant) & 2.162 & .795 & .063 & .008 \\
& $\mathrm{X}$ & .025 & .040 & .619 & .538 \\
\hline
\end{tabular}

Sumber : Olahan data

Hasil uji heteroskedastisitas menggunakan uji glejser hasil signifikansi dari variabel bebas sebesar 0,538 diatas dari nilai standar signifikansi 0,05. Sehingga dapat disimpulkan bahwa tidak terjadi masalah heteroskedastisitas.

Berdasarkan Tabel 6 dapat dibentuk persamaan (model) regresi yaitu:

$Y=8,141+0,506 X$

Dengan variabel $X$ adalah literasi keuangan dan variabel $Y$ adalah keputusan investasi. Adapun interpretasi dari model regresi dimuka adalah :

$\mathrm{a}=8,141$, Jika literasi keuangan $=0$ (nol) maka besarnya keputusan investasi sebesar 8,141 poin.

$\mathrm{B}=0,506$ Jika literasi keuangan meningkat sebesar 1 (satu) satuan maka keputusan investasi akan mengalami peningkatan sebesar 0,506 poin.

Tabel 8

Hasil Uji Simultan

\begin{tabular}{|c|l|l|l|l|l|l|}
\hline \multicolumn{2}{|l|}{ Model } & Sum of Squares & df & Mean Square & F & Sig. \\
\hline \multirow{3}{*}{1} & Regression & 912.284 & 1 & 912.284 & 71.130 & $.000^{\mathrm{b}}$ \\
& Residual & 1218.438 & 95 & 12.826 & & \\
\cline { 2 - 4 } & Total & 2130.722 & 96 & & & \\
\hline
\end{tabular}

Sumber : Olahan data

Diperoleh nilai $F_{\text {hitung }} 71,139>\mathrm{F}_{\text {tabel }}$ 3,94, maka berdasarkan kriteria pengujian data dapat diketahui bahwa $\mathrm{H}_{\mathrm{a}}$ diterima dan $\mathrm{H}_{0}$ ditolak, artinya literasi keuangan secara bersama-sama (simultan) berpengaruh signifikan terhadap keputusan investasi.

Tabel 9

Uji Parsial

\begin{tabular}{|l|l|l|l|l|l|l|}
\hline \multirow{2}{*}{ Model } & Unstandardized Coefficients & Standardized Coefficients & \multirow{2}{*}{ S } & Sig. \\
\cline { 3 - 7 } & B & Std. Error & Beta & 6.846 & .000 \\
\hline \multirow{2}{*}{1} & (Constant) & 8.141 & 1.189 & & .654 & .000 \\
\cline { 2 - 7 } & $\mathrm{X}$ & .506 & .060 & .654 & & .434 \\
\hline
\end{tabular}

Sumber: Olahan data

Berdasarkan nilai signifikansi dari tabel coefficients diperoleh nilai signifikansi sebesar $0,000<0,05$, sehingga dapat disimpulkan bahwa variabel Literasi Keuangan (X) berpengaruh terhadap variabel Keputusan Investasi 
Gita Sari Gustika dan Hasanah Yaspita, Pengaruh Literasi Keuangan Terhadap Keputusan Investasi Mahasiswa STIE Indragiri Rengat

(Y). Berdasarkan nilai $\mathrm{t}$ : diketahui $\mathrm{t}$ hitung sebesar 8,434 $>\mathrm{t}$ tabel 1,985, sehingga dapat disimpulkan bahwa variabel Literasi Keuangan (X) berpengaruh terhadap variabel Keputusan Investasi (Y).

Tabel 10

Model Summary

\begin{tabular}{|l|l|l|l|l|}
\hline Model & R & R Square & Adjusted R Square & Std. Error of the Estimate \\
\hline 1 & $.654^{\mathrm{a}}$ & .428 & .422 & 3.581 \\
\hline
\end{tabular}

Sumber : Olahan data

Tabel 10 di atas menjelaskan besarnya nilai korelasi/ hubungan $(\mathrm{R})$ yaitu sebesar 0,654. Dari output tersebut diperoleh koefisien determinasi ( $\mathrm{R}$ Square) sebesar 0,428, yang mengandung pengertian bahwa pengaruh variabel bebas (Literasi Keuangan) terhadap variabel terikat (Keputusan Investasi) adalah sebesar 42,8\%.

\section{Simpulan}

Berdasarkan hasil penelitian dapat disimpulkan sebagai berikut :

1) Hasil Analisis Regresi Linear Sederhana, Jika literasi keuangan sama dengan 0 (nol) maka besarnya keputusan investasi sebesar 8,141 poin, jika literasi keuangan meningkat sebesar 1 (satu) satuan maka keputusan investasi akan mengalami peningkatan sebesar 0,506 poin.

2) Hasil uji parsial (Uji $\mathrm{t}$, diperoleh $\mathrm{t}$ hitung sebesar 8,434 $>\mathrm{t}$ tabel 1,985 , sehingga dapat disimpulkan bahwa variabel Literasi Keuangan (X) berpengaruh terhadap variabel Keputusan Investasi (Y).

3) Hasil Uji Simultan diperoleh nilai $F_{\text {hitung }} 71,139>F_{\text {tabel }}$ 3,94, maka berdasarkan kriteria pengujian data dapat diketahui bahwa $\mathrm{H}_{\mathrm{a}}$ diterima dan $\mathrm{H}_{0}$ ditolak, artinya literasi keuangan secara bersama-sama (simultan) berpengaruh signifikan terhadap keputusan investasi.

\section{Daftar Pustaka}

Anggraeni, B. D. (2015). Pengaruh Tingkat Literasi Keuangan pemilik Usaha Terhadap Pengelolaan Keuangan. Jurnal Vokasi Indonesia. Vol. 3, No. 1.

Fransinatra z, Iskandar y, Gustika gita, S. (2020). Jurnal Manajemen dan Bisnis. Jurnal Manajemen Dan Bisnis, 9(2), 26-44. https://doi.org/https://doi.org/10.34006/jmbi.v9i2.224

Halim, Abdul 2015, Analisis Investasi di Aset Keuangan, Mitra Wacana Media, Jakarta.

Hartono,Jogiyanto.(2016). Teori Portofolio dan Analisis Investasi. Edisi Kesepuluh. Yogyakarta.

Herlianto, Didit. (2013). Manajemen Investasi Plus Jurus Mendeteksi Investasi Bodong. Yogyakarta: Gosyen

Huston, S. J. (2010). Measuring Financial Literacy. The Journal of Consumer Affairs, 44(2), 296-317.

Jacob, K., Hudsonn, S. \& Bush, M. (2000). Tools for survival: an analysis of financial literacy programs for lowerincome families. Chicago: Woodstock Institute.

Mandell, Lewis, and Linda Schmeid Klein. (2007). Motivation and financial literacy. Financial Services Review, 16 (2): $105-116$

Monticone, Chiara. (2010). Financial Literacy and Financial Advice Theory and Empirical Evidence. http://arno.uvt.nl/show.cgi?fid=115261 diakses pada tanggal 16 Desember 2018.

Otoritas Jasa Keuangan (OJK) (2016), Strategi Nasional Literasi Keuangan Indonesia, Otoritas Jasa Keuangan, Jakarta

Putri, N. M. D. R., \& Heni, R. (2017). Pengaruh Tingkat Financial Literacy dan Faktor Sosiodemografi terhadap Perilaku Keputusan Investasi Individu. E-Jurnal Ekonomi dan Bisnis Universitas Udayana. Vol.6 No.9, 34073434

Sadono, Sukirno. (2016). Makro Ekonomi Teori Pengantar. Jakarta: PT.Rajagrafindo Persada.

Tandelilin, E. (2010). Portofolio dan Investasi Teori dan Aplikasi (Edisi pertama). Yogyakarta: Kanisius. 